\title{
Chinese Trade Bilateralism and Latin America: The Case of China-Chile Free Trade Agreement
}

\author{
El bilateralismo de China con Latinoamérica: \\ el caso del Tratado de Libre Comercio China-Chile
}

\author{
DOI: $10.32870 /$ mycp.v9i27.687
}

\author{
Martín de la Torre Medina ${ }^{1}$
}

\begin{abstract}
In 2001 China's entrance to the World Trade Organization represented a major threat to developing countries including those from Asia and Latin America and the Caribbean. Countries such as Mexico were worried about its inclusion for China's competitiveness was a great challenge to face; others such as Chile took advantage of the benefits of being part of the multilateral forum and began negotiations to formalize bilateral cooperation. What are the main characteristics of bilateralism? What benefits can China bring as a trading partner within the framework of an FTA? Can the Chilean case be taken into consideration for other countries to pursue bilateral agreements with China? This paper has the objective of answering those questions through an analysis of the scope of trade agreements, the Chinese integration to the World Trade Organization and its free trade agreements network, and the integration of China with Latin America, with a special focus on its relationship with Chile as the first country in the continent to have an agreement with China.
\end{abstract}

Keywords: free trade agreements, bilateralism, Latin America and the Caribbean, China, ChinaChile Free Trade Agreement.

\section{Resumen}

En 2001, la entrada de China a la Organización Mundial del Comercio representó una gran amenaza para los países en desarrollo, incluyendo los de regiones como Asia y América Latina y el Caribe. Países como México mostraron su preocupación debido al reto que representaba China en cuestiones de competencia; otros, como Chile aprovecharon las ventajas de formar parte de la OMC como un foro multilateral de comercio y comenzaron negociaciones con China para formalizar la cooperación bilateral. ¿Cuáles son las principales características del bilateralismo? ¿Qué beneficios puede aportar China como socio comercial en el marco de un TLC? ¿Puede el caso de Chile ser tomado en cuenta en el marco de futuros acuerdos comerciales entre China y otros países? Este artículo tiene el objetivo de responder a dichas preguntas mediante un análisis de los alcances de los tratados comerciales, la integración de China a la OMC y su red de tratados de libre comercio, y la integración de China con la región de América Latina y el Caribe con énfasis en su relación con Chile, al ser el primer país en el continente en tener un acuerdo con el país asiático.

Palabras clave: tratados de libre comercio, bilateralismo, Latinoamérica y el Caribe, China, Tratado de Libre Comercio China-Chile.

Artículo recibido el 11 de marzo de 2019 y dictaminado el 02 de junio de 2020.

1. Licenciado en Comercio Internacional. Estudiante del Master on Global Politics and Transpacific Studies. México. ORCID: https://orcid.org/0000-0001-9911-7513. Correo electrónico: martindelatorre25@gmail.com 


\section{Introduction}

Nations negotiate agreements as part of an integration process with other countries in their region or even overseas to obtain gains from trade, strengthen their domestic policy reforms, increase the group of countries with bargaining power in bigger organizations such as the World Trade Organization, guarantee access to the trading partners' markets, and to promote security arrangements (Whalley, 1998; Magee, 2017). Agreements can vary in scope, members, and negotiations, and the benefits may also vary in terms of how strong the economy of a nation is.

The objective of this paper is to determine the reasons that motivated China to pursue negotiations of Free Trade Agreements after it acceded to the World Trade Organization and to analyze its interest on Latin American nations, particularly Chile, which was the first nation (in the continent) that China signed a Free Trade Agreement (FTA) with.

To accomplish the objective, the data analyzed in this paper comes from official institutions, such as the Ministry of Finance and Commerce from China, as well as from international organizations' databases including the World Bank, the International Monetary Fund, and uN-Comtrade.

In the third section of the paper, data from the World Integrated Trade Solution (WITS) — a World Bank tool— is taken to review the Chilean imports and exports partners and products, since, the information it provides include the data from other major databases such as the UN-Comtrade, UNCTAD, the WTO, and the World Bank per se.

The paper is divided into three sections: the first one aims to describe what are the regional trade agreements deepening on free trade agreements and Aggarwal's ideas of bilateralism; section 2 will focus on China's open-door policies considering China's engaging on FTAs; the last section will deepen on the Chinese rapprochement to Latin America and the Caribbean region focusing on the Sino-Chilean relation and the China-Chile FTA signed on 2006.

\section{Regional Trade Agreements and Regional Integration in Asia-Pacific}

The World Trade Organization (WTO) defines regional trade agreements (RTAs) as reciprocal arrangements between two or more partners and, depending on the conditions, they can be free trade, preferential trade or customs union agreements; its success depends on the countries that are involved, if they 
are similar, the effects will always be higher. Since its creation in 1994, the organization has received more than 500 RTAs being in force 304 as of January 2020 (WTO, 2020a). This paper is focused on free trade agreements.

Free trade agreements (FTAs) can be understood as tools used by countries to open up foreign markets by reducing trade barriers and creating a more stable and transparent environment for trade and investment among the signers; in other words, FTAs "are groupings of countries within which tariffs and non-tariff barriers between the members are generally abolished but with no common trade policy toward non-members" (Organization for Economic Cooperation and Development [OECD], 2001), i.e. the benefits provided by this type of agreements are only for those nations that are associated to them; some examples are the European Free Trade Association (EFTA) signed by Norway, Iceland, Switzerland and Liechtenstein, the Pacific Alliance signed by Mexico, Colombia, Peru, and Chile, or the many bilateral agreements signed by Mexico, China, the United States, etc.

RTAs can have either positive or negative effects on the world's welfare depending on the effects they cause in terms of trade diversion and trade creation: the former occurs "because the RTA means there is a lower tariff on imports of goods from within the regional trading area than on imports of goods from outside the trading bloc" (Magee, 2017, p. 279), in other words, with a tariff preference, some goods imported by a country from outside the area of the RTA will be imported from countries within the RTA — trade is then diverted from countries outside the RTA after all the goods are imported without tariffs from inside the RTA-. On the other hand, "trade creation occurs when a country eliminates tariffs on imports from a partner country and some of a country's domestic production is replaced by imports from a more efficient producer in the trading partner" (Viner, 1950; Magee, 2017, p. 279), this means that trade is created when a country "A" expand its benefits by minimizing the costs of production by using imported parts from country "C" and sells a final good to country "B". Magee (2017) thus concludes that trade diversion is becoming irrelevant since the benefits brought by RTAs are been translated into trade creation.

The condition on whether an RTA is positive or negative also lies in the design and the implementation of the tools that will be used, and on the scope of liberalization, the members agreed to apply. The simplest measure of integration is the trend on the imports from regional partners in the total imports of a region, thus successfulness happens when the regional agree- 
ments help to increase trade within its members compared to the trade of those nations with the rest of the world. However, three caveats must be taken into consideration to succeed: first, reductions in tariffs for all partners; second, there should be trade stimulation as a consequence of the removal or reduction of processes and trade costs related to the commercial operations, such as efficient customs procedures, logistics, and transport, etc.; finally, the agreements can consider non-trade issues, such as investment, services, and labor that will impact their application (World Bank, 2005).

Countries decide to sign FTAs for different reasons, including economic and social ones. The impact of the agreements helps to determine the extent to which political and social objectives are achieved, thus success is derived from how willing countries are to change their policies and to liberalize and accept economic adjustments (World Bank, 2005). Also, it is important to consider that the success of an RTA in each country depends on each country itself and that the impact of joining one will be determined by its performance in the region they belong to and in the world economy as a whole.

Each region/country has chosen its scope of agreements depending not only in their commercial needs, but also on how integrated the countries belonging to it are, for example, the North American Free Trade Agreement (now United States-Mexico-Canada Agreement) that embodies the case of an FTA with the implication of tariffs and non-tariff reduction/elimination, or the European Union, a customs union with all members integrated into a single market and policies.

To be integrated, countries require cooperating in certain topics such as trade and investment, transport and infrastructure, financial policies, as well as in the provision of common public goods, such as shared natural resources, security, or education. However, they also must consider the risks that may appear within the integration, i.e. the differences in economy and growth perspectives, geography, sovereignty, as well as the impacts on trade and investment and the allocation of resources and the members that the agreement will have.

In line with Aggarwal (2006), bilateralism (or the pursuit of countries to sign bilateral FTAs) responds to the fears toward multilateralism based on a variety of political-economic factors with the governments structuring their trading relationship within three elements: goods, individual situations, and existing institutions. In other words, signing bilateral free trade agreements reduces economic and political risks as well as transaction costs with the signers 
pursuing to expand the trade between them by lowering tariff and non-tariff barriers and creating trade, investment expansion, and financial stability.

Three main reasons explain bilateralism in Asia Pacific: "the awareness of the weakness of existing regional institutions and initiatives, perceptions of positive demonstration effects from regional agreements in other parts of the world, and the changing domestic economic interests" (Ravenhill, 2003, p. 3). The former, goes in hand with APEC's weakness on defining its principal objective on whether liberalizing trade or facilitating it through cooperation and how it was going to operate, whether in a framework of a unilateral nondiscriminatory liberalization or in such of a negotiated preferential liberalization; another concern from countries in the region towards multilateralism was the failure of the Seattle Ministerial Meeting of the WTO in 1999, as well as the fail in Doha Round from 2001. The second reason was the governments' interest in bilateral agreements stimulated by the perceived success of arrangements, particularly preferential trade ones, as well as those such as NAFTA and Mercosur or the EU that showed deeper integration. The third one comprehends the multilateral agreements tendency to focus on cooperation in security issues rather than in economic or trade-related ones; also, the private sector was not involved most of the times in the governments of the regional agreements negotiated, and its inclusion to the game benefited both sectors, public and private.

In the last years, countries like China have been moving towards this tendency of bilateralism but have also considered other multilateral initiatives such as the Regional Comprehensive Economic Partnership, the Shanghai Cooperation Organization, or the Belt and Road Initiative. The next section will focus on the Chinese signed FTAs and the importance its authorities have given to bilateral arrangements.

\section{China's Integration to the WTO and its FTAS Network}

Before the 1980s China was an isolated economy with almost null trade with the rest of the world, however, in 1978 the central government headed by leader Deng Xiaoping, adopted a principle known as "opening to the outside world" or "open-door policy" as a national policy that helped to change China's development strategy "from one based on self-sufficiency to one of active participation on the world market" (Yanqing, 2014, p. 56). This government- 
controlled strategy helped the Republic to transform, gradually, into one of the most important trading nations worldwide.

As a developing country, China needed external resources to accelerate its modernization process, from economic ones, to financial and technological. To get the economic support, China not only had to narrow the differences between itself and the market economies, but also to reshape the Communist Party Politics, and change the state-society relations; there were seven new strategies implemented by the new government, to fulfill the task of applying the open-door policy, these strategies, or aspects, were rooted on different reasons, for example, China's efforts to modernize learning from the Western powers but maintaining its traditional culture, and the failure of the Cultural Revolution that led to a negative perception of the authorities and its institutions (Guocang, 1986).

The first strategy was to implement a new trade approach and abandon the Maoist approach to self-sufficiency and isolation; consequently, it exploited its natural and human resources to develop labor-and natural-resource-intensive industries, expand its foreign trade, and integrate the Chinese economy to the world economy by decentralizing trade institutions and allowing the Chinese to negotiate with international companies.

The second aspect was related to technology transfer: the Chinese leaders were interested in obtaining the benefits from industrial market economies, so the authorities reduced the duties and taxes on imported items related to energy, computers, and high-technology; they also decided to open its doors to scientists, researchers, and engineers from Japan, the United States, among other countries. The third one is linked to the establishment of four special economic zones (SEZs) to attract foreign direct investment (FDI). These SEZs were settled in Shenzhen, Zhuhai, Xiamen, and Shantou, cities to which the authorities granted special rights, such as autonomy to make most of its decisions. Industrial, scientific, and construction foreign projects enjoyed what Guocang describes a "tax holiday" with almost zero political control by the Communist party in the commercial activities. Also, in 1984 Beijing decided to establish, in similar ways as it did with the SEZs, 14 coastal cities such as Shanghai or Tianjin that enjoyed the ability signing of contracts with foreign investors.

The fourth strategy encompasses the government's new attitudes towards the international financial institutions - China joined the World Bank (WB) and the International Monetary Fund (IMF) in 1980 and became active in 
institutions like the United Nations' Industrial Development Organization-. During the 1980s, the WB supported many industrial, construction, agricultural and educational projects and gave China low-interest loans.

The fifth is related to the academic arena, where exchange programs were established by universities so that students could go to industrialized market economies to study and get the know-how in specific production processes to be implemented once they were back in China; social sciences, businesses, and law were topics that were also boosted. The sixth aspect went hand in hand with the tourism industry. In the 1980s China opened areas that were not accessible to people, and the government encouraged local authorities and construction companies to take projects overseas. Some companies were established in Africa and some others in the Middle East (see Table 1).

Table 1

Chinese strategies in the implementation of the open-door policy

\begin{tabular}{l|l}
\hline Strategy & Task \\
\hline 1 & New trade strategy far from Maoist approach \\
\hline 2 & Technology transfer from Western industrialized countries. \\
\hline 3 & Establishment of sEZs to boost FDI \\
\hline 5 & Entrance to international institutions such as wB and the IMF \\
\hline 6 & $\begin{array}{l}\text { In the academic arena, links were made with universities from market } \\
\text { economies to get information on processes and know-how. }\end{array}$ \\
\hline $\begin{array}{l}\text { Tourism industry improved; encouragement from the government to invest } \\
\text { outside China }\end{array}$ \\
\hline
\end{tabular}

Source: Guocang (1986).

Thanks to the impact of the Open-Door Policy, the Chinese economy was able to grow in an already globalized world. Moreover, in 1986 China started the process to obtain its GATT/WTO membership, in what became the longest process in the history of the institution - China was admitted until 2001-. During the first decade of China's membership in the WTO, Chinese authorities tried to change the perception of the nation's economy for it to be recognized as a market one using the strategy of RTAs aiming to avoid anti-dumping investigations (Gao, 2010).

After it acceded to the World Trade Organization, China started to sign Free Trade Agreements with different organizations and countries in Asia and in Europe, starting negotiations with ASEAN (Association of South-East 
Asian Nations) in 2002, followed by an agreement with Pakistan in 2007 and with New Zealand in 2008. Currently, China has FTAs with Chile, Peru, and Costa Rica, in Latin America; Switzerland, and Iceland, in Europe; and with the Republic of Korea and Australia in the Pacific Region (see Table 2 and Figure 1) (China's Ministry of Finance and Commerce [Mofcom], 2020).

\section{Table 2}

Chinese Free Trade Agreements (FTA) Network

\begin{tabular}{|c|c|}
\hline \multirow[t]{15}{*}{ China's FTAs } & China-Maldives FTA \\
\hline & China-Georgia FTA \\
\hline & China-Australia FTA \\
\hline & China-Korea FTA \\
\hline & China-Switzerland FTA \\
\hline & China-Iceland FTA \\
\hline & China-Costa Rica FTA* \\
\hline & China-Peru FTA* \\
\hline & China-Singapore FTA \\
\hline & China-New Zealand FTA \\
\hline & China-Chile FTA* \\
\hline & China-Pakistan FTA \\
\hline & China-ASEAN FTA (CAFTA) \\
\hline & $\begin{array}{l}\text { Mainland and Hong Kong Closer Economic and Partnership } \\
\text { Arrangement }\end{array}$ \\
\hline & Mainland and Macau Closer Economic and Partnership Arrangement \\
\hline \multirow{10}{*}{$\begin{array}{l}\text { FTAs Under } \\
\text { Negotiation }\end{array}$} & Regional Comprehensive Economic Partnership, RCEP \\
\hline & China-GCC (Gulf Cooperation Council) FTA \\
\hline & China-Sri Lanka FTA \\
\hline & China-Japan-Korea FTA \\
\hline & China-Israel FTA \\
\hline & China-Norway FTA \\
\hline & China-Mauritius FTA \\
\hline & China-Moldova FTA \\
\hline & China-Panama FTA** \\
\hline & China-Palestine FTA \\
\hline
\end{tabular}


Chinese Trade Bilateralism and Latin America: The Case of China-Chile Free Trade Agreement

\begin{tabular}{l|l}
\hline \multirow{2}{*}{$\begin{array}{l}\text { FTAs Under } \\
\text { Consideration }\end{array}$} & China-Colombia FTA Joint Feasibility Study ${ }^{* * * *}$ \\
\cline { 2 - 2 } & China-Fiji FTA Joint Feasibility Study \\
\cline { 2 - 2 } & China-Nepal FTA Joint Feasibility Study \\
\cline { 2 - 2 } & China-Papua New Guinea FTA Joint Feasibility Study \\
\cline { 2 - 2 } & China-Canada FTA Joint Feasibility Study \\
\cline { 2 - 2 } & China-Bengal FTA Joint Feasibility Study \\
\cline { 2 - 2 } & China-Mongolia FTA Joint Feasibility Study \\
\hline Preferential & Asia Pacific Trade Agreement (APTA) \\
\hline
\end{tabular}

* Countries in Latin America with an in-force FTA with China (Costa Rica, Chile and Peru).

** Panama started negotiations with China to sign a FTA on January 2018.

*** China and Colombia are studying the impacts of signing a FTA; they are not yet negotiating.

Source: Mofcom (2020). Retrieved from: http://fta.mofcom.gov.cn/english/index.shtml

\section{Figure 1}

\section{Countries that China has an in-force FTA with}

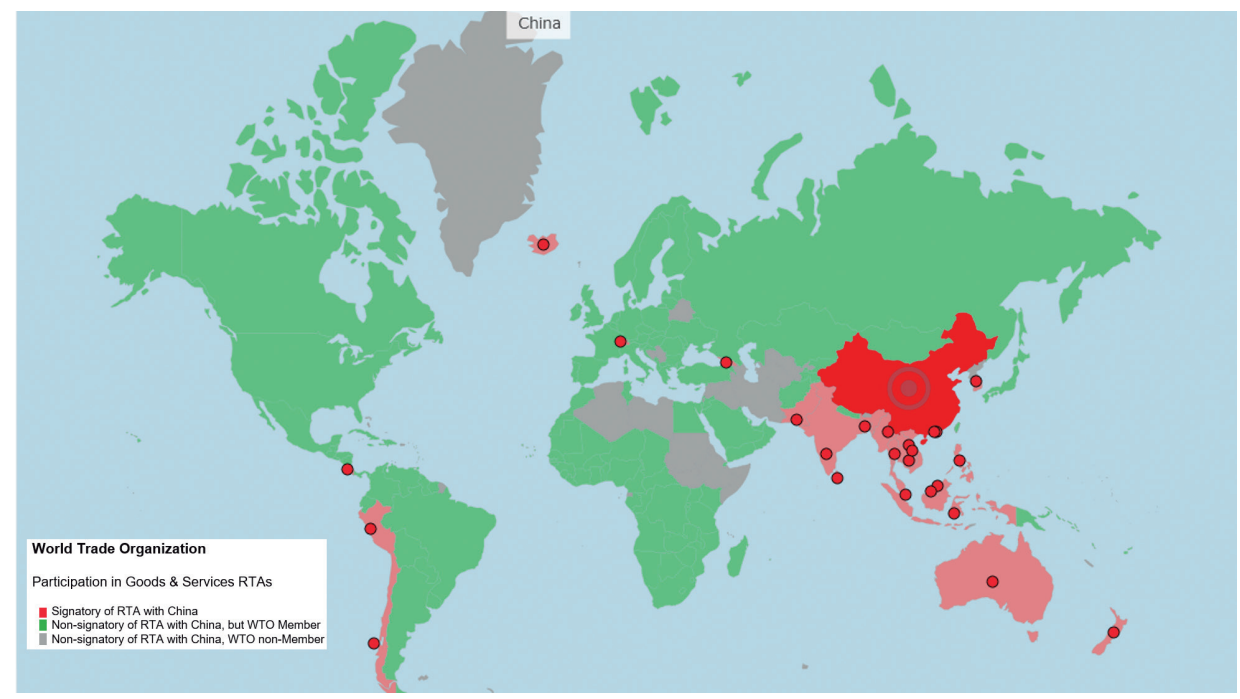

Source: WTO (2020b). Retrieved from: https://www.wto.org/english/tratop

Since China signed its first bilateral FTA with ASEAN on November 2004 (negotiations started in 2002), an increasing number of domestic actors entered into Chinese FTA policymaking, and with this, a major debate — between protection- 
ist and liberal forces regarding trade and market liberalization - came into the scene (Yang, 2010). Despite there are no 'interest groups' or lobbying figures in China, there are coalitions that have been formed within some industries that might influence determining the scope and application of an FTA.

According to Yang (2010), protectionist industries are agriculture and services and investments. The Ministry of Agriculture (MOA) was the major opponent, for example, to the opening of Chinese agriculture in the framework of the China-Australia Free Trade Agreement. The Ministry gained power and influence as it became the farmers' representative in the government. The second industry (services and investment), was protective on issues regarding both, economic security with more developments towards services rather than manufacturing, and monopoly profits in telecommunication and cultural services, as well as attention to mining and transportation (these industries were reluctant to open their doors to an FTA). "Comprehensive" FTAs intend to cover all three scopes (goods, services, and investment) being always the former the one with more benefits and action field.

The second group, the liberals, has China's Ministry of Finance and Commerce (Mofcom) and manufacturing sectors as the major proponents of trade liberalization in the nation. Mofcom officials generally propose reforms and liberalization of market policies with the idea that competition enhances productivity and free trade benefits consumers; however other domestic sectors are still reluctant to the idea. On the other hand, manufacturing sectors, especially labor-intensive industries are supportive of FTAs, and they have even been more liberalized than agriculture and services giving the industry an important comparative advantage on FTA negotiations (Yang, 2010).

Like any other country that pursues an agenda of creating a FTAs' network, Beijing's one has its own political and economic motivations. The political ones, according to Yang (2010), lie in the use of FTAs as instruments to strengthen political relations with the other party and also to gain force in the decisionmaking processes in bigger forums such as ASEAN or even WTO (the China-ASEAN Summit held in 2000 is seen as a Chinese move towards its accession to the World Trade Organization). The economic motivations to pursue FTAs are four: first, they help to expand exports and to diversify exports markets, expecting growth in manufacturing goods production; second, they help reduce costs for Chinese customers and producers; third, the agreements help China to attract direct investment and to participate in projects that require overseas foreign direct investment (OFDI); finally, FTAs enhances the competition and productiv- 
ity of the industries (Yang, 2010). Thus, it is possible to say that authorities and industries in China pursue almost the same advantages of implementing an FTA.

\section{China and Latin America and the Caribbean (LAC) Region: its Main Partners and the Case of Chile}

During the 1990s, when the number of FTAs increased significantly, countries in Latin America and the Caribbean (LAC) region also took part in this kind of integration processes such as, Mercosur and NAFTA; however, according to the International Monetary Fund (IMF, 2017) there are important missing points in the networks made by nations in the region since the three most important economies do not have FTAs among them: Mexico, Argentina, and Brazil. It was until the end of the global financial crisis of 2008-2009 that LAC progressed in trade liberalization with some reduced or eliminated tariffs but still with some work to do if the region is compared with others that are better integrated.

As China keeps rising, global commercial interactions experience dramatic growth and transformation. A worldwide affectation of the Chinese rise is the implications in the commercial relations that the United States has with other countries as Beijing is playing as a counterbalance to Washington's power not only in Asia but also in the West's developing countries (particularly in Latin American and the Caribbean (LAC) region) (Zuo \& Esparza, 2019).

While comparing LAC region growth since 1980 with China's growth, it is possible to see how China has had a greater gross domestic product since. However, at the beginning of the 2000s with the latter's entrance to the WTO, until 2008, the differences became smaller. According to information obtained from the International Monetary Fund (IMF, 2020), by 2021-2023 the difference on growth between both will be reduced as China's economy is not having the same expansion as in the last decade, and with LAC slowly rises; even with that, China's economic growth will be higher at least by three points.

Comparing individually the economic growth between China and its main partners in LAC (those with whom it has signed agreements) - Peru, Costa Rica and Chile - it is evident that Chinese GDP growth has been - at least since 1992 after the nation recovers its political crisis that started with the Tiananmen outbreaks of 1989- higher thanks to the open-door reforms. As it can be seen during the 1990s Costa Rica and Chile had similar economic growth to China (Peru had it during the mid-1980s). However, after 1994-95, 
China's growth increased dramatically leaving the LAC countries behind. With the Chinese economic debacle after the peak reached in 2009, the difference in growth has been decreasing, but according to the graphs, the tendency of China's growth being higher than its partners will not change in the mediumterm (see Figure 2).

\section{Figure 2}

Real GDP comparison between China and Costa Rica, Peru and Chile
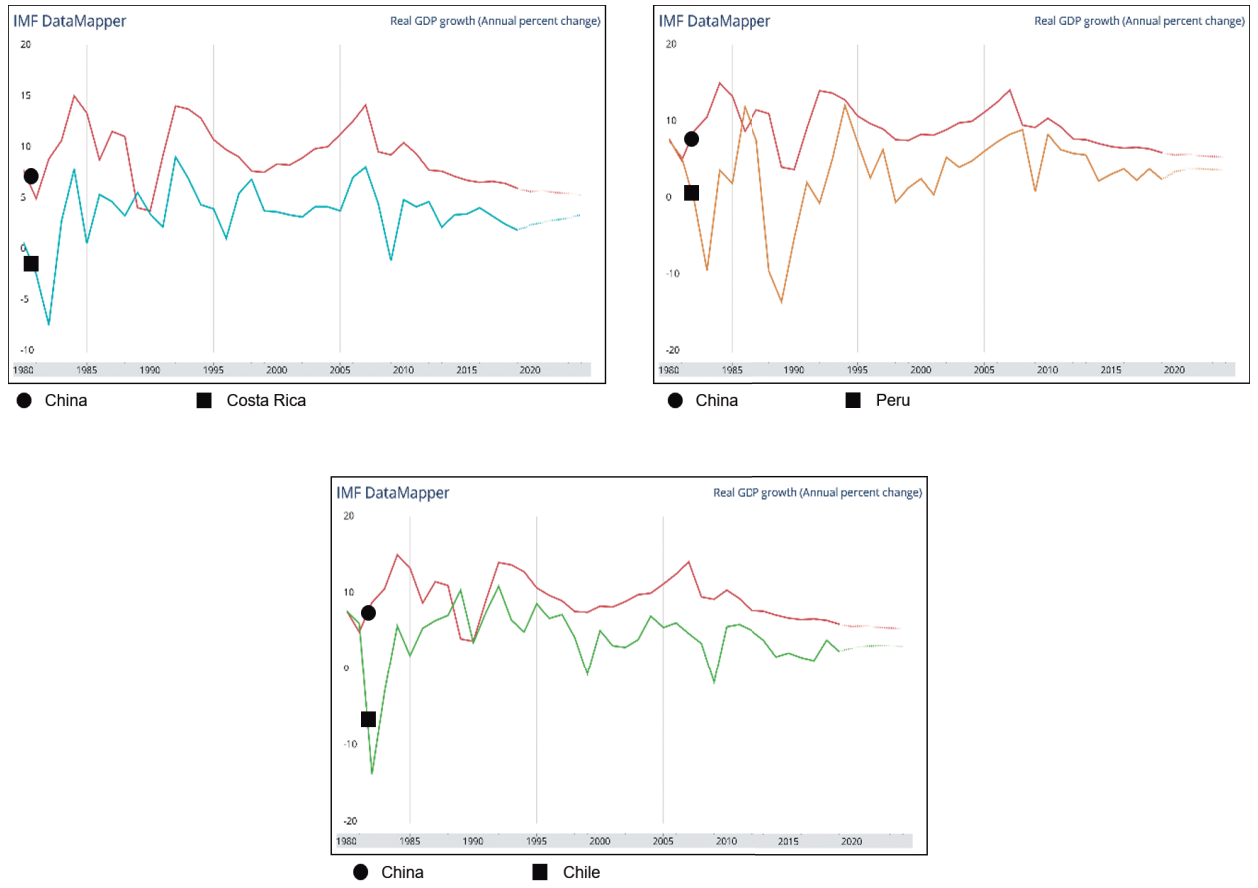

Source: IMF (2020).

The integration process of China with other regions started since the 1990s, however, it was during the second half of this decade when it engaged to LAC. From 2000 to 2017 the exports jumped from 1\% to 10\% making China the third-largest export market of the Region. On the other hand, imports jumped from $2 \%$ to $18 \%$ in the same analyzed period. This last data reflects that China is the second-largest import destination (Zuo \& Esparza, 2019). 
Even when the statistics show a deep integration between China and LAC, according to Zuo \& Esparza (2019), all actors should develop a fairer model of trade, considering previous experiences that LAC faced with bigger economies, that characterized by taking advantage of the resources of the region. This model would prevent abuses and might be useful as a tool to promote even more relations with broader scopes within them.

Concerning the market information, LAC countries import mainly manufactured products from China, while China concentrates its imports in raw materials such as iron, oil, copper, and soybeans with a specific group of providers including Brazil, Venezuela, Argentina, Peru, and Chile (Zuo \& Esparza, 2019); this last two (Peru and Chile), alongside Costa Rica have in force-free trade agreements with China, while Panama is in negotiations to sign one.

While studying their relation scholars have concluded that there are two waves of Chinese economic targets in the Latin American region, the first one being from 2001 to 2013 in which China aimed to establish strategic partnerships through investments, loans and a strong interest in companies linked to the mineral extraction (oils and minerals); the second (2014-), comprises a new Chinese approach towards innovation, green infrastructure and sustainable development pursuing the same objective of diversification of trade and investment. Both waves lead to the case study of Chile as it was capable to attract the Chinese attention to developing a closer trade relationship that successfully concluded in one of the most important free trade agreements signed by China.

\subsection{China-Chile Free Trade Agreement}

The relationship between China and Chile dates back to the 1970s during the government of Salvador Allende making Chile the first South American country to establish diplomatic relations with China; during the 1990s, with the exports boom and economic liberalization processes in Latin America, Chile prioritized the relations with China and in 1999 it was the first nation in LAC to support China's accession to the WTO (Gachuz, 2012; Ministerio de Relaciones Exteriores, 2020).

Heine (2006) states that, among others, one of the main reasons on pursuing and signing an FTA, lies in the fact that the commercial relationship between both countries flourished significantly from 2001 to 2005, with Chile's exports to China being more than tripled and Chinese imports more 
than doubled. After some rounds of negotiations held in 2002, both countries signed their FTA during the 2005 APEC Conference in South Korea addressing not only tariff reduction but also topics such as market access, commercial defense, rules of origin and phytosanitary rules, as well as labor cooperation, security and environmental responsibility (Gachuz, 2012) - Chile became the first individual country that signed an FTA with China.

The FTA entered in to force in October 2006, and its main objectives were to extend to zero duty $97 \%$ of the products in ten years, as well as strengthening cooperation, investing being one of the key topics besides trade. Between 2008 and 2012 two supplementary agreements were settled by both parties in terms of trade in services and investment, leading the Asian country to become Chile's largest trading partner (see Figure 3), largest export destination, and largest source of imports (Mofcom, 2019).

\section{Figure 3}

Chilean imports and exports main partners (2018)
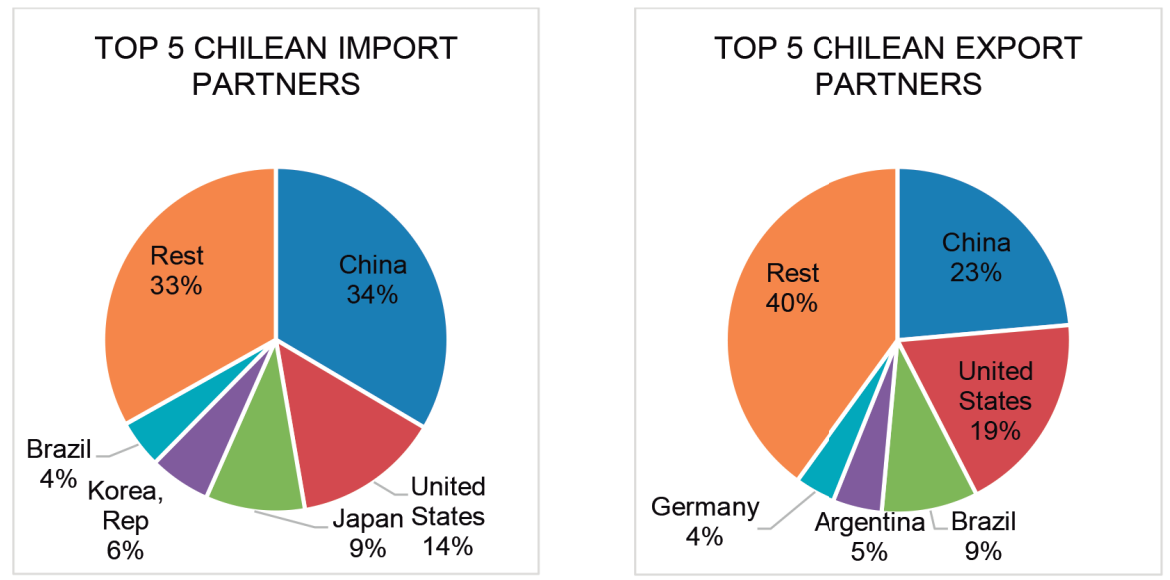

Source: World Bank (2020).

In 2012 China and Chile agreed to "develop their bilateral relationship toward a strategic partnership and in 2016 both nations raised relations to a comprehensive strategic partnership" (Borquez, 2019, p. 12), considered the highest diplomatic figure Chinese authorities give to trading partners; within this distinction both accepted to update their market access towards 
services, value-management platforms, research and development, and to the establishment of production centers. Since the FTA entry to force in 2006, Chilean balance of trade with China has behaved positively with exports growing more than $300 \%$ and imports up to $280 \%$, being 2018 the year with the highest balance of the last 14 years (see Figure 4) (UN Comtrade, 2020).

\section{Figure 4}

Trade balance between Chile and China from 2006 to 2019

(Million us dollars)

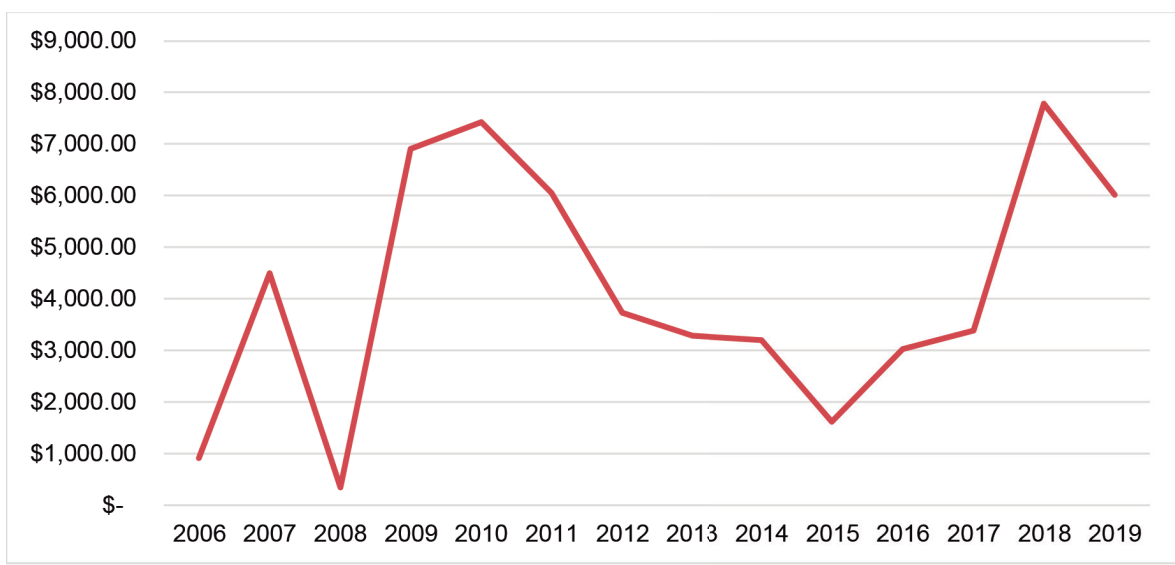

Source: UN-Comtrade (2020).

Table 3

Chilean Import Product Share from China in 2018

\begin{tabular}{l|c}
\hline Product Group & Import Product Share (\%) \\
\hline Mach and Elec & 33.18 \\
\hline Textiles and Clothing & 18.13 \\
\hline Metals & 12.01 \\
\hline Miscellaneous & 8.41 \\
\hline Transportation & 6.87 \\
\hline Rest & 21.4 \\
\hline
\end{tabular}

Source: World Bank (2020). 
Table 4

Chilean Exports Product Share to China in 2018

\begin{tabular}{l|c}
\hline Product Group & Export Product Share (\%) \\
\hline Stone and Glass & 42.23 \\
\hline Chemicals & 36.78 \\
\hline Minerals & 9.32 \\
\hline Animal & 5.7 \\
\hline Metals & 2.28 \\
\hline Rest & 3.69 \\
\hline
\end{tabular}

Source: World Bank (2020).

According to the World Bank (2020), 33\% of the total Chile imports account for mechanical and electrical products, including high-new technology and integrated circuits followed by textiles and metals; on the other hand, $78 \%$ of the Chilean exports to China account for stone and glass - or mineralsand chemicals including mechanical ores slags from copper, iron, and zinc, among others; meaning that Chile is one of the most important raw material suppliers for the Chinese industry (see Table 3 and Table 4).

Despite the economic and commercial success resulted after the ratification of the FTA, some sectors had affectations due to the conditions of the implementation of the treaty since most of the Chinese interests rely on minerals. These other sectors that should be considered can be categorized in value-added products and services to maintain the competitiveness with China (Gachuz, 2012); but it might take more time considering the export product share seen in Table 4 since products like minerals, animals and metals, with the rest of the exportable products account for the $20 \%$ of the total share.

In June 2016, in the framework of the 10th anniversary of the FTA entrance to force, former Chilean Ambassador to China, Jorge Heine provided an interview with the Chinese journal China Today in which he accepted that China accounted for an important part of Chilean foreign trade. According to the situation of the South American country before the agreement, Heine states a couple of concerns, the first one was the foreign trade policy of Chile towards seeking a bilateral or multilateral FTA: it was never thought that the country was going to open its door to an Asian nation; the second was China per se as "China commands vigorous trade and tends to have surpluses with the vast majority of countries" (Heine, in China Today, 2016), however, he 
implied, "the FTA ended up being the right decision" with Chile having trade surplus since 2006.

The impacts of the Chile-China FTA represented an increase in the Chilean exports of $70 \%$ annually as a result of a well-planned strategy launched towards Chile's comparative advantage on fresh products, this condition allowed its agricultural sector to grow $6 \%$ while the overall economy was growing at a rate of $2 \%$. Thanks to the agreement's approach, for example, China became the largest market for Chilean wine, displacing the United Kingdom, leading into a huge process of diversification (Heine, in China Today, 2016), a process that started at the beginning of the 2000s and that has been evolving towards better opportunities for both nations.

\section{Conclusion}

Since the mid-2000s, China's necessity of natural resources became evident with its rapprochements with the LAC region and the negotiation processes followed to achieve stronger relationships with some countries with trade being the main topic or issue to assess. The case of the Chile-China FTA became an important topic in the international trade agenda during the years of negotiation and entry to force (2002-2006) since their agreement represented the first time a Latin American country signed one with China when it was seen as a threat to developing countries in the LAC region, and as a massive competitor in the world's commercial arena.

According to Li (2014), the Chile-China FTA comprises one of China's strategies to assure the purchase and distribution of natural resources, particularly copper and other minerals that account for more than $75 \%$ of Chile's total exports to China, thus the success of their relationship is based on two factors: on one hand, a country - Chile- focused on exporting products and materials from industries related to primary commodities and raw materials rather than diversifying the exports; and on the other hand with a country — China — taking advantage, through commerce, of those minerals and resources but at the same time exporting to Chile all kind of products, from miscellaneous to machinery and electronics and textiles and clothing; thus, Chile took advantage of its condition as a raw material and natural resources supplier while benefitting its intern market with the Chinese exports at a lower cost. 
The Chilean case can be considered by countries willing to strengthen their relationship with China since, as it has been mentioned, the ratification of an FTA also means having open-door policies towards investment; Peru and Costa Rica, countries which China has in-force trade agreements with, were seen as potential partners by China with Peru having similarities concerning Chile on the supply of natural resources - minerals - , and with Costa Rica representing a geographical advantage to reduce shipping and production costs given the Chinese rapid increase on crude oil imports from Venezuela and Ecuador.

The case of the Chile-China FTA, in Mexico, for example, is far from being replicated because of some conditions existing in the Mexico-China relationship including, mainly, the existing competition between both nations in the US market, as well as the influence of power groups related to industries - for example, textile and shoe industries - inside Mexico that were affected once China became a member in the WTO. It is important, then, to ensure that a well-defined strategy is made towards implementing a free trade area to make sure that both countries will be benefitted. This strategy should consider as many industries as possible to prevent negative outcomes on a given country.

Well negotiated Free Trade Agreements can be helpful to develop trade networks and to gain market access; they are frameworks in which countries can be benefited from creating trade by reducing and eliminating tariff and non-tariff barriers, as well as promoting instruments to accelerate transit and customs processes; however, its importance and scope have lately been extended to other non-trade related issues including foreign direct investment, migration, intellectual property, as well as sanitary and phytosanitary measures that have helped signatories and negotiators to strengthen and/or create new bonds between countries and its industries.

\section{References}

Aggarwal, V. K. (2006). Bilateral Trade Agreements in the Asia-Pacific, Introduction in V.K. Aggarwal, \& S. Urata (Eds.), Bilateral Trade Agreements in the Asia-Pacific: Origins, Evolution and Implications. London, UK: Routledge. Borquez, A. (2019). Exploring the nontraditional foreign investment in Sino-Latin American relations: The Chilean case. Competition and Regulation in Network Industries, 20(10), 1-16. doi: https://doi. org/10.1177/1783591719877592 
China's Ministry of Finance and Commerce (MOFCOM). (2020). China's Free Trade Agreements. Retrieved from: http://fta.mofcom.gov.cn/english/ index.shtml

China Today. (2016). The China-Chile FTA was the right decision. Retrieved from: http://www.china.org.cn/world/2016-06/01/content_38580498.htm

Gachuz, J. C. (2012). Chile's Economic and Political Relationship with China. Journal of Current Affairs, 41(1), 133-154. doi: https://doi.org/10.1177\% 2F186810261204100105

Gao, H. (2010). China on the World Stage: A Trade Law Perspective. Proceedings of the Annual Meeting. American Society of International Law, 104, 532-535. doi: https://doi.org/10.5305/procannmeetasil.104.0532

Guocang, H. (1986). China's Open-Door Policy, 1978-1984. Journal of International Affairs, 39(2), 1-18.

Heine, J. (2006). China, Chile and free trade agreements. Estudios Internacionales, 38(152), 143-147.

International Monetary Fund (IMF). (2017). Cluster Report - Trade Integration in Latin America and The Caribbean. Washington, DC.

International Monetary Fund (IMF). (2020). IMF Data Mapper: Real GDP Growth. Retrieved from: https://www.imf.org/external/datamapper/ NGDP_RPCH@WEO/OEMDC/ADVEC/WEOWORLD

Li, Y. (2014). China's Free Trade Agreement Diplomacy. School of Social Sciences and Humanities (Doctoral dissertation, University of Adelaide). Retrieved from: https://digital.library.adelaide.edu.au/dspace/ bitstream/2440/103486/2/02whole.pdf

Magee, C. (2017). The Increasing Irrelevance of Trade Diversion. KYKLOS, 70(2), 278-305. doi: https://doi.org/10.1111/kykl.12138

Ministerio de Relaciones Exteriores. (2020). Relación Bilateral Chile-China. Retrieved from: https://chile.gob.cl/china/relacion-bilateral

Organization for Economic Cooperation and Development (OECD). (2001). Free Trade Area. Retrieved from: https://stats.oecd.org/glossary/detail. asp?ID $=3128$

Ravenhill, J. (2003). The new bilateralism in the Asia Pacific. Third World Quarterly 2(24), 299-317. doi: https://doi.org/10.1080/0143659032000074600

un COMTRADE. (2020). Database. Retrieved from: https://comtrade.un.org/ data

Viner, J. (1950). The Customs Union Issue. American Political Science Review, 4(44), 1055-1055. 
Whalley, J. (1998). A Future WTO Trade Round? International Studies 35(4). doi: https://doi.org/10.1177/0020881798035004002

World Bank. (2020). Regional Integration. Retrieved from: http://www.worldbank.org/en/topic/regional-integration/overview

World Bank. (2005). Regional Trade Agreements: Effects on Trade. Global Economic Prospects 2005.

World Integrated Trade Solution. (2020). Retrieved from: https://wits.worldbank.org/Default.aspx?lang=en

World Trade Organization (WTO). (2020a). Regional trade agreements. Retrieved from: https://www.wto.org/english/tratop_e/region_e/region_e. htm

World Trade Organization (WTO). (2020b). Participation in Regional Trade Agreements. Retrieved from: https://www.wto.org/english/tratop

Yang, J. (2010). China's pursuit of free trade agreements: Is China exceptional? Review of International Political Economy, 17(2), 238-26. doi: https://doi. org/10.1080/09692290903337799

Yanqing, J. (2014). Openness, Economic Growth and Regional Disparities. Berlin: Springer.

Zuo, P. \& Esparza, G. (2019). Rising China’s Multipolar Diplomacy towards Latin America and the Caribbean: Challenges Ahead. Mexico y la Cuenca del Pacifico, 8(23), 23-48. doi: https://doi.org/10.32870/mycp.v8i23.601 